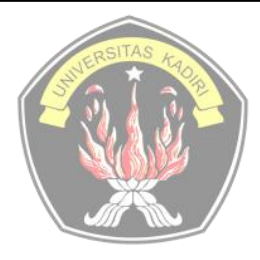

Tersedia online di

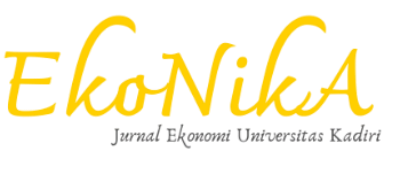

\title{
Kajian Etnometodologi: Pola Pemasaran Berpihak Masyarakat Pedesaan Kediri Pada Ritel Tradisional
}

\author{
Samari ${ }^{1}$, Ema Nurzainul Hakimah ${ }^{2}$ \\ 1,2, Fakultas Ekonomi Universitas Nusantara PGRI Kediri \\ email: ${ }^{1}$ samari@unpkediri.ac.id, ${ }^{2}$ emahakimah@unpkediri.ac.id
}

\section{Artikel History:}

Artikel masuk : 10-03-2020

Artikel revisi : 17-03-2020

Artikel diterima : 10-04-2020

Keywords:

dimensi budaya, peritel tradisional, pola pemasaran berpihak

Style APA dalam mensitasi artikel ini: [Heading sitasi] Satu, N. P., \& Dua, N. P. (Tahun). Judul Artikel. Ekonika : Jurnal Ekonomi Universitas Kadiri, v(n), Halaman awal Halaman akhir. [heading Isi sitasi]

\section{ABSTRAK}

Penelitian ini bertujuan untuk mengungkap dan mengetahui makna dibalik pola pemasaran peritel tradisional, sikap pelanggan atas penerapan pola tersebut dan lebih dalam menganalisis interaksi antara peritel tradisional dengan pelanggannya serta mempelajari norma-norma subyektif yang terjadi dalam pola pemasaran tersebut. Penelitian ini merupakan penelitian kualitatif dengan pendekatan etnometodologi. Penelitian dilakukan dengan cara pengamatan langsung dan wawancara mendalam pada peritel tradisional dan pelanggannya. Informan dipilih dengan kriteria $5 \mathrm{R}$ menempati wilayah pedesaan Kediri, yang dipilih adalah desa Blabak kecamatan Kandat kabupaten Kediri dan kelurahan Blabak kecamatan Pesantren kota Kediri. Pengamatan sendiri dilakukan pada saat terjadi transaksi jual beli di toko tradisional masingmasing yang selanjutnya dilakukan wawancara terbuka untuk mengungkapkan norma-norma subyektif yang terjadi dalam pola pemasaran tersebut. Hasil dari pengamatan dan wawancara mendalam pada penelitian ini menunjukkan bahwa keempat dimensi budaya Hofstade, yaitu Power Distance, Collectivism, Femininity, Uncertainty Avoidance berkembang positif dimana peritel menempatkan dan menjadikan diri sebagai mitra, saudara yang berempati kepada pelanggan dengan menggunakan sikap dasar saling mempercayai untuk kelancaran pemenuhan kebutuhan masing-masing. Nilai-nilai luhur budaya masyarakat Kediri dalam berjual beli "nyaur nggowo, podho mlakune" yang dilandasi kepercayaan tinggi melahirkan loyalitas pelanggan semakin kuat, terlebih lagi ketika peritel tradisional juga mempraktikkan dimensi kualitas jasa reliability, assurance, tangibles, empaty dan responsiveness.

\section{ABSTRACT}

This study aims to uncover and find out the meaning behind traditional retailer's marketing patterns, customer attitudes toward the application of these patterns and more in analyzing the interactions between traditional retailers and their customers and to learn the subjective norms that occur in these marketing patterns. This research is a qualitative research with ethnometodology approach. The study was conducted by direct observation and in-depth interviews with traditional retailers and their customers. Informants were selected with criteria $5 R$ 
occupying rural areas of Kediri, the chosen ones were Blabak village, Kandat district, Kediri district and Blabak village, Pesantren district, Kediri city. The observations themselves were made during the sale and purchase transactions at each traditional store, which then conducted open interviews to reveal the subjective norms that occur in the marketing pattern. The results of observations and in-depth interviews in this study indicate that the four dimensions of Hofstade's culture, namely Power Distance, Collectivism, Femininity, Uncertainty Avoidance develop positively where retailers place and make themselves as partners, brothers who empathize with customers by using a basic attitude of mutual trust for fluency fulfillment of each other's needs. The noble values of the culture of the people of Kediri in buying and selling "nya nggowo, podho mlakune" based on high trust give birth to stronger customer loyalty, especially when traditional retailers also practice the service quality dimension of reliability, assurance, tangibles, empathy and responsiveness.

\section{PENDAHULUAN}

Direktur Asosiasi Pengusaha Indonesia (Apindo) Research Institute, Agung Pambudi mengatakan "Hingga saat ini industri ritel khususnya ritel tradisional, masih memiliki ruang untuk terus bertumbuh. Meskipun ritel tradisional harus bersaing dengan industri ritel modern. Hal ini dikarenakan ritel tradisional masih menjadi tempat favorit belanja masyarakat karena faktor lokasi dan kemuudahan mendapatkan barang kebutuhan sehari-hari, sekaligus yang tidak kalah penting adalah kayanya nilai-nilai sosial dalam hubungan antara ritel tradisional dengan para pembeli yang berlandaskan kepercayaan" (Liputan6.com,23 Nopember 2018). Data Badan Pusat Statistik (BPS) tahun 2016 menyebutkan sector riil memiliki kontribusi 15,24\% terhadap PDB dan menyerap tenaga kerja sebesar 22,4 juta atau 31,81\% dari tenaga kerja non pertanian. Distribusi toko ritel Indonesia pada tahun 2017 masih didominasi oleh toko tradisional sebesar $82,3 \%$.

Dalam riset awal yang dilakukan ditemukan fakta bahwa di beberapa desa di wilayah Kabupaten dan Kota Kediri, mengalami peningkatan pelaku ritel tradisional rata-rata dua sampai tiga orang pelaku usaha. Fenomena ini terjadi karena usaha ritel tradisional ini dinilai lebih mudah dan lebih cepat dalam memulai usaha guna mendapatkan keuntungan. Modal usaha yang tidak terlalu besar, sebagai pengisi waktu luang, memanfaatkan ruang kosong di rumah, cepat kembali modal, dan cepatnya mendapatkan keuntungan menjadi alasan pendorong dipilihnya usaha ini.

Demikian pula dalam hal suasana toko yang harus diperbaiki, peritel tradisional juga menyadari bahwa konsumen membutuhkan kenyamanan dalam berbelanja, meskipun sejauh ini belum maksimal dilakukan (Hakimah \& Aliami, 2017). Ketrampilan pengelolaan dan 
wawasan yang terbatas tentang ritel tidak menjadi alasan mereka memutuskan untuk tetap memilih ritel sebagai usaha mereka untuk mendapatkan penghasilan dan memiliki usaha sendiri. Bahkan dalam keadaan perekonomian yang mendesak, masyarakat kita sering kali menjadikan usaha ritel sebagai salah satu kesempatan untuk mendapatkan pendapatan dan kesempatan kerja. Ritel juga membuktikan telah memberikan harapan besar pada masyarakat untuk mempunyai usaha sendiri. Hal ini dibuktikan bahwa 400 orang terkaya di Amerika Serikat menurut Forbes adalah wirausahawan sukses bidang ritel (Levy \& Weitz, 2001). Dikutip dari detik.com (www.detik.com, 2016:06:08), menyatakan bahwa saat ini persaingan antar pelaku usaha ritel cukup ketat dimana terjadi perkembangan pada toko-toko modern mencapai 31,4\%. Fenomena bermunculannya pelaku usaha dibidang ritel yang berbentuk toko, mini market, department store dan pasar swalayan (supermarket) sanga berimbas baik terhadap pertumbuhan perekonomian. Hal ini memberikan fenomena positif untuk tumbuh dan berkembangnya ritel tradisional di Indonesia, diungkapkan oleh Roy Mande (Aprindo) bahwa di semester I - 2018 tumbuh 7 - 7,5\% di mana angka ini lebih tinggi dibandingkan tahun 2017 yaitu sebesar 5\% (Pablo, 2018).

Secara umum karakter konsumen Indonesia tergolong sangat khas., menurut Majalah Marketing Agustus 2016, konsumen Indonesia memiliki 12 karakter unik, yaitu berpikir jangka pendek, tidak terencana, gagap teknologi, orientasi pada konteks, suka merek luar negeri, religius, gengsi, kuat di subkultur, suka pamer, suka ikut-ikutan, kurang peduli lingkungan, dan suka bersosialisasi. Pengaruh budaya terhadap perilaku konsumen dan peritel tradisional dapat diartikan sebagai bentuk utuh dari keyakinan, nilai dan kebiasaan yang dipelajari oleh suatu kelompok tertentu yang mengarahkan pada perilaku dalam bertransaksi jual - beli. Keyakinan maupun nilai merupakan dasar mental yang membentuk sikap seseorang untuk melakukan sesuatu, sehingga metode yang sesuai dalam penelitian ini adalah etnometodologi. Pemilihan metode etnometodologi dianggap mampu mendeskripsikan nilai hidup yang dipahami oleh masyarakat pedesaan Kediri yang setiap harinya melakukan transaksi jual beli. Hal ini disebabkan setiap harinya untuk pemenuhan kebutuhan sehari - hari masyarakat pedesaan Kediri masih banyak tergantung pada ritel - ritel tradisional di lingkungannya. Karakter konsumen Indonesia yang unik dan dibalut dengan landasan utama pelaku usaha yaitu kepercayaan inilah yang kemudian menjadi perspektif menarik yang akan dikaji dalam penelitian ini, sehingga diharapkan ditemukan konsep hubungan bersinergi dalam usaha maupun budaya sosial yang semakin kuat sebagai model penggerak perekonomian rakyat.

Lebih lanjut hasil penelitian ini diharapkan dapat mengungkap kearifan lokal masyarakat khususnya hubungan antara peritel tradisional dan pelanggannya ditengah pasar bebas yang 
berkembang. Penelitian ini difokuskan pada peritel tradisional (toko kelontong) dengan luas area penjualan kurang dari $10 \mathrm{~m}^{2}$ dan pelanggannya yang berada di wilayah pedesaan dan pinggiran kota. Wilayah komunitas peritel tradisional dan pelanggan ini meliputi daerah pedesaan kecamatan Kandat dan kelurahan kecamatan Pesantren.

Penelitian pemasaran berpihak yang melihat dari sisi peritel dan konsumen, sejauh peneliti ketahui belum pernah dilakukan apalagi dipublikasikan. Untuk menggali lebih dalam tentang budaya peritel dan konsumen pedesaan Kediri digunakan dimensi budaya yang dikembangkan oleh Hofstede (1997) yaitu power distance, individualism/collectivism, masculinity/femininity dan uncertainty avoidance.

\section{TINJAUAN PUSTAKA}

\section{Budaya}

Budaya telah banyak digunakan dalam segmentasi pemasaran. Budaya dan sub-budaya merupakan elemen yang penting untuk membantu memahami perilaku para konsumen. Budaya merupakan sebuah kesatuan antara sikap, perilaku, dan symbol yang dimiliki oleh sekelompok orang. Contohnya adalah orang Hispanik, orang Cina, orang kulit hitam dan yang lainnya. Perilaku konsumen dipengaruhi oleh budaya yang biasanya diwariskan dari satu generasi pada generasi selanjutnya.

Menurut Hawkins, et al. (2007;43) budaya merupakan kesatuan secara menyeluruh yang mencakup pengetahuan, keyakinan, seni, hokum, moral, kebiasaan dan kapabilitas lainnya serta kebiasaan-kebiasaan yang dikuasai individu sebagai anggota masyarakat. Sedangkan menurut Mowen and Minor (2002) kebudayaan didefinisikan sebagai seperangkat pola perilaku yang diperoleh secara sosial dan diekspresikan melalui symbol-symbol dan car-cara lain kepada anggota masyarakat.

Pengaruh budaya terhadap perilaku konsumen, dapat didefinisikan sebagai keseluruhan dari keyakinan, nilai dan kebiasaan yang dipelajari oleh suatu kelompok masyarakat tertentu yang mengarahkan perilaku konsumsinya. Keyakinan maupun nilai merupakan konstruk mental yang mempengaruhi sikap yang kemudian berpengaruh terhadap kecenderungan seseorang untuk bertindak terhadap perilaku tertentu. Sedangkan kebiasaan terdiri perilaku rutin sehari-hari yang merupakan cara berilaku yang dapat diterima.

Budaya tidak muncul begitu saja, namun dikuasai oleh anggota masyarakat melalui proses pembelajaran. Keluarga mengajarkan tentang nilai-nilai yang telah diyakini kebenarannya dalam bersikap dan berperilaku. Demikian juga masyarakat melakukan kontrol 
sosial terhadap warganya agar memiliki nialai-nilai, keyakinan dan kebiasaan seperti yang diharapkan sebagian besar anggota masyarakat.

Selain itu, budaya akan muncul dengan cara meniru. Seseorang akan meniru perilaku keluarga, teman atau figur yang menjadi panutannya. Dunia pendidikan juga mengajarkan apa yang harus dilakukan, mengapa hal itu dilakukan dan bagaiman melakukannya, sehingga menjadi suatu budaya.

Bidang pemasaran juga membagi masyarakat menjadi sub kelompok yang lebih kecil (sub budaya) yang terdiri dari orang-orang yang memiliki kesamaan etnis, kebiasaan dan cara berperilaku. Pembagian sub budaya ini didasarkan pada berbagai macam variabel sosio budaya dan demografis seperti kebangsaan, agama, lokasi geografis, etnis, usia, jender dan bahkan status pekerjaan (Sciffman and Kanuk, 2000: 382)

Kebangsaan, agama, lokasi geografis, etnis, usia dan jender merupakan factor yang menyebabkan anggota kelompoknya lebih menerima nilai kelompoknya dan akhirnya akan mempengaruhi perilakunya. Pengaruh sub budaya pada perilaku konsumen tergantung pada beberapa factor, diantaranya adalah : (1) keunikan sub budaya, semakin kuat suatu sub budaya mempertahankan identitasnya agar berbeda dengan yang lain, makin besar potensi pengaruhnya; (2) homogenitas sub budaya, sub budaya dengan nilai-nilai yang homogen cenderung memiliki pengaruh yang kuat pada anggotanya; (3) eksklusivitas sub budaya, sub budaya secara sengaja memisahkan diri sebagai sebuah kelompok terpisah untuk mempertahankan dan melindungi keyakinannya.

\section{Komponen - komponen Budaya}

\section{a. Norma}

Budaya menyediakan nilai (values) yaitu apa yang dianggap baik dan tidak baik, apa yang dijunjung tinggi sangat erat kaitannya dengan norma-norma yang ada dalam masyarakat. Terdapat dua jenis norma yang umum (Mowen and Minor, 2002), yaitu : norma yang dijalankan (enacted norm) dan norma kresive (cresive norm). Norma yang dijalankan biasanya dinyatakan dalam bentuk undang-undang atau bentuk peraturan lainnya, sedangkan norma kresive meskipun tidak tertulis secara formal namun sangat kuat tertanam pada anggota masyarakat. Norma kresive tertanam dalam budaya masyarakat dan hanya dipelajari dalam interaksi anggota masyarakat yang menganut kebudayaan tersebut, dan biasanya dalam bentuk kebiasaan, adat istiadat dan konvensi.

\section{b. Mitos}

Mitos merupakan kisah yang mengungkap nilai-nilai utama dan cita-cita suatu masyarakat. Mitos akan membantu menjelaskan asal usul eksistensi, mengungkap 
seperangkat nilai bagi masyarakat dan menyediakan model-model sikap seseorang. Terciptanya mitos sangat penting bagi pemasar.

\section{c. Simbol}

Setiap budaya memiliki seperangkat simbol dimana para konsumen akan terikat dengan hal tersebut. Simbol dapat dianalogikan dengan aktivitas tertentu, bentuk tertentu maupun warna tertentu.

\section{d. Nilai}

Dalam suatu masyarakat nilai budaya menunjukkan arti dari kepercayaan mengenai keadaan akhir yang ideal dan cara berperilaku, merupakan standar untuk membimbing tindakan, sikap dan keputusan. Apabila budaya suatu masyarakat berubah maka nilai individu yang membentuk masyarakat juga akan berubah.

\section{e. Ritual}

Merupakan aktivitas yang bersifat simbolis yang merupakan serangkaian langkahlangkah (berbagai perilaku) yang muncul dalam rangkaian yang pastu dan terjadi berulang-ulang. Ritual ditetapkan oleh masyarakat bukan oleh individu, orang lebih menyadari apa yang terjadi dalam suatu ritual dibandingkan dalam kebiasaan, memiliki arti simbolik yang lebih besar dibandingkan kebiasaan dan memiliki lebih banyak pengaruh yang berhubungan dengannya.

\section{Budaya dan Perilaku Konsumen}

Budaya adalah seperangkat nilai, keyakinan dan kebiasaan yang diperoleh atau dipelajari, yang diterima oleh kelompok masyarakat tertentu secara turun - temurun sebagai suatu kesatuan yang membantu mengerahkan perilaku para anggotanya. Nilai yang dimaksudkan disini mengandung beberapa kriteria yaitu : (1) nilai merupakan panduan bagi perilaku yang dianggap tepat dari segi budaya; (2) nilai bersifat tahan lama dan sulit diubah; (3) nilai tidak dikaitkan dengan suatu obyek atau situasi spesifik; dan (5) nilai diterima secara luas oleh anggota masyarakatnya. Keyakinan mengandung sejumlah pernyataan mental atau verbal seseorang yang merefleksikan pengetahuan dan penilaiannya tentang suatu hal tertentu. Sedangkan kebiasaan merupakan perilaku yang jelas mengenai cara-cara yang dapat diterima dari segi budaya untuk suatu perilaku dalam situasi yang spesifik (Suprapti, 2010:210)

Keterkaitan antara budaya dengan perilaku konsumen dapat diketahui dari nilai - nilai akhir (terminal values), nilai-nilai instrumental, dan atribut-atribut produk yang menjadi pertimbangan utamanya. Nilai akhir merupakan tujuan yang ingin dicapai dan akan dicapai melalui nilai-nilai instrumental. Dalam kaitannya dengan perilaku konsumsi, nilai instrumental 

pembelian.

Budaya mempengaruhi perilaku konsumen pada beberapa tahap proses pengambilan keputusan konsumen, kelompok masyarakat dari beberapa negara memiliki perilaku pembelian yang berbeda. Budaya pada level makro akan menjelaskan perbedaan dalam perilaku pembelian pada sekelompok masyarakat.

Budaya menjelaskan tentang aturan tak tertulis pada masyarakat. Salah satu pandangan pada budaya adalah menganggap budaya sebagai 4 (empat) dimensi yang juga bisa diukur (Hofstede, 1997). Dimensi-dimensi tersebut antara lain Power Distance, Indiviualism/collectivism, Masculinity / Femininity, Uncertainty Avoidance.

\section{a. Perbedaan Kekuasaan (Power Distance)}

Perbedaan kekuasaan merupakan sebuah kondisi dimana komunitas yang kekuasaannya lebih lemah harus bisa menerima fakta bahwa kekuasaan didistribusikan secara tidak seimbang. Dalam masyarakat yang perbedaan kekuasaannya besar, terdapat pengakuan tingkatan didalam masyarakat dan tidak menerima persamaan tingkatan. Dalam masyarakat dengan perbedaan kekuasaan yang rendah, tidak mengakui adanya perbedaan dan menganggap adanya persamaan tingkatan didalam masyarakat.

\section{b. Individualisme dan Kolektivisme (Individualism and Collectivism)}

Pada kebudayaan individualis, orang lebih menjaga diri mereka sendiri, merefleksikan sejauh mana individu mengharapkan kebebasan pribadi. Pada kebudayaan kolektivis, orang menerima tanggungjawab dari keluarga, kelompok masyarakat, suku sebagai bentuk kesetiaan. Pada kebudayaan individualis, identitasnya secara perorangan dan kolektivis berdasarkan hubungan sosial yang saling memiliki. Kebudayaan individual menggunakan komunikasi verbal yang lebih eksplisit dan kebudayaan kolektivis menggunakan komunikasi yang lebih implisit.

\section{c. Maskulinitas dan Feminitas (Masculinity / Femininity)}

Kebudayaan maskulinitas lebih menekankan pada kesuksesan yaitu terfokus pada nilai kinerja dan pencapaian yang nampak. Nilai dominan pada kebudayaan feminitas adalah perhatian pada orang lain dan kualitas kehidupan, hubungan persaudaraan, dan peduli pada yang lemah. Penghargaan dan penampilan sangat penting pada maskulinitas, dan status sangat penting untuk menunjukkan kesuksesan. Kebudayaan feminitas mempunyai orientasi masyarakat, dan status tidak begitu penting. Pada budaya maskulinitas, ada perbedaan peranan substansial antara pria dan wanita sedangkan dalam budaya feminitas perbedaan peranannya lebih kecil. 


\section{d. Penghindaran Ketidakpastian (Uncertainty Avoidance)}

Penghindaran ketidakpastian adalah sebuah kondisi dimana orang merasa terancam oleh ketidakpastian serta ambiguitas dan mencoba untuk menghindari atau mengelak dari hal tersebut. Dalam masyarakat dengan tingkat penghindaran ketidakpastian yang rendah akan lebih santai sehingga praktik lebih tergantung prinsip dan penyimpangan akan lebih bisa ditoleransi, ada kepercayan pada tokoh. Ketidakpastian mengenai masa depan adalah sebagai dasar kehidupan masyarakat. Masyarakat yang tingkat ketidakpastiannya tinggi akan mengurangi dampak ketidakpastian dengan teknologi, peraturan dan ritual.

\section{METODE PENELITIAN}

\section{Jenis Penelitian}

Penelitian ini merupakan penelitian kualitatif dengan pendekatan etnometodologi. Secara normatif , etnometodologi dapat didefinisikan sebagai studi tentang “ ......everyday activities asa members method for makng those same activities visibly - rational - and reportable - for - all- practical- purpose i.e. "accountable" as organisations of commonplace everyday activities". Jadi , fokus studi etnometodologi adalah aktivitas yang bersifat rutin dan merujuk pada aktivitas keseharian kelompok bukan individu ( Garfinkel dalam Kamayanti,2015).

\section{Kehadiran Peneliti}

Pada penelitian ini peneliti yang bertindak sebagai seorang etnometodologis langsung menjadi participant observer agar dapat langsung memperoleh bentuk aktivitas dan merelasikannyalangsung dengan indeksikalitas dan refleksivitas.

\section{Lokasi Dan Subyek Penelitian}

Dalam penelitian ini lokasi yang diteliti wilayah pedesaan yaitu desa Blabak kecamatan Kandat kabupaten Kediri dan kelurahan Blabak kecamatan Pesantren Kota Kediri, yang mana dalam penelitian awal telah diperoleh data pertumbuhan pelaku ritel baru dan bertahannya para pelanggan di masing-masing ritel tradisional atau toko kelontong tersebut. Subyek dalam penelitian ini adalah para peritel tradisional dan pelanggan ritel tersebut.

\section{Pemilihan Informan}

Informan dalam penelitian kualitatif merupakan aspek yang paling penting. Oleh karenanya, penting sekali untuk memilih informan sesuai dengan kriteria berikut ini:

\section{Relevance}

Yang dikatakan relevance dalam penelitian ini berarti informan terkait dengan masalah yang diteliti.

\section{Recomendation}


Disini informan didapat atas dasar rekomendasi dari orang - orang yang terpercaya.

\section{Rapport}

Untuk menggali informasi lebih dalam, maka sebagai peneliti harus memastikan apakah informan bisa dekat dengan peneliti atau tidak.

\section{Readiness}

Informan dalam penelitian kualitatif harus benar - benar dipastikan siap diwawancarai.

\section{Reassurance}

Informan yang diambil benar - benar bicara sesuai dengan kebenaran.

\section{Sumber Data}

Sumber data merupakan salah satu bagian penting dalam penelitian. Pentingnya data untuk memenuhi dan membantu serangkaian permasalahan yang terkait dengan fokus penelitian. Sumber data yang digunakan dalam penelitian ini adalah data primer dan sekunder. Yang mana data didapat dari informan langsung dan untuk melengkapi data dari informan, peneliti juga mencari informasi berupa dokumen - dokumen grafis, foto - foto, rekaman, video.

\section{Prosedur Pengumpulan Data}

Proses pengumpulan data pada penelitian ini menggunakan beberapa teknik diantaranya:

1. Observasi

Dalam observasi ini peneliti melakukan pengamatan dan yang sistematis terhadap gejala - gejala yang diteliti. Peneliti melakukan observasi awal dengan cara mengunjungi, mengamati dan berinteraksi langsung selama 3 bulan dengan peritel dan pelanggannya.

2. Wawancara mendalam

Wawancara yang dilakukan peneliti dalam penelitian ini merupakan alat rechecking atau pembuktian terhadap informasi atau keterangan yang diperoleh sebelumnya. Wawancara ini dilakukan dengan tujuan untuk memperoleh keterangan dengan tanya jawab sambil bertatap muka antara pewawancara dengan informan dengan atau tanpa pedoman wawancara, yang mana dalam hal ini pewawancara dan informan dapat terlibat dalam kehidupan sosial yang relatif lama.

3. Dokumentasi

Dalam kegiatan penelitian ini , peneliti mengambil data berupa catatan, gambar, buku agenda, dan sebagainya terkait budaya dan nilai-nilai selama interaksi dalam bertransaksi jual beli.

\section{Tahapan Analisis Dan Teknik Penarikan Kesimpulan}

Dalam mempelajari aktivitas keseharian yang disepakati bersama anggota kelompok, Grafinkel menetapkan tiga tahap analisis yaitu : 
1. Tahap pertama: Analisis Indeksikalitas

Tahap ini merupakan tahap untuk mencari dan memahami tema yang disetujui oleh kelompok peritel tradisional dan kelompok pedagang. Pada tahap ini peneliti akan membuat indeks - indeks tema melalui ungkapan maupun bahasa tubuh peritel dan pelanggannya.

2. Tahap kedua : Analisis Refleksivitas

Setelah peneliti melakukan pengamatan dan menemukan ekspresi indeksikalitas, maka penulis akan menelaah refleksivitas dari ekspresi tersebut. Hal ini akan ditampilkan pada kertas kerja seperti berikut :

Tabel 3.1 Kertas Kerja Pencarian Kesepakatan Umum (Common Understanding)

\begin{tabular}{|l|l|l|}
\hline Informan & Percakapan (Interaksi) & $\begin{array}{l}\text { Pemahaman Bersama (Implisit) tentang } \\
\text { interaksi }\end{array}$ \\
\hline $\begin{array}{l}\text { 1.Informan 1 } \\
\text { 2. Informan 2 } \\
\text { 3.dst }\end{array}$ & $1 \ldots \ldots \ldots \ldots$ & $1 \ldots \ldots \ldots . .$. \\
\hline
\end{tabular}

3. Tahap ketiga : Analisis Aksi Kontekstual

Tahap ketiga studi etnometodologi dalam penelitian ini adalah mengungkapkan aktivitas keseharian bersifat praktis yang dapat dikenali (recognizable) da dapat dilaporkan (visible). Mahkota penelitian etnometodologi adalah suatu penjelasan tentang keteraturan dan keterkaitan antara ekspresi indeksikalitas, rasionalisasi atas ekspresi indeksikalitas dan akan berakhir pada sebuah aksi indeksikalitas. Hal ini akan terlihat seperti gambar dibawah ini :

\section{Gambar 3.1 Order antara ekspresi dan aksi Indekskalitas}

\section{ekspresi indeksikalitas organisasi \\ rasionalisasi (studi refleksivitas) \\ aksi indekskalitas \\ organisasi}

\section{Tahap keempat : Penyajian Common Sense Knowlwdge of Social Structures}

Penelitian ini bermuara pada pemahaman pola struktur sosial. Dari etnometodologi ini kami peneliti akan mendapatkan gambaran tentang indeks yang dilakukan dalam keseharian dan kesepakatan komunitas. Dari hasil gambaran ini, pemahaman relasi indeks dan refleksivitas akan mengungkap aksi indeksikalitas yang terbentuk. Akhirnya pemahaman ini akan mengarah 
pada budaya umum. Jadi jelas apa saja dampak dari pengelolaan digital marketing serta faktor apa saja menyebabkan hasil pengelolaan digital marketing belum maksimal

\section{HASIL \& PEMBAHASAN}

\section{Hasil dan Pembahasan berdasarkan Perspektif Peritel Tradisional}

\section{a. Pelanggan adalah Saudara}

Pelanggan ritel tradisional atau toko kelontong adalah warga sekitar yang masih mempunyai hubungan persaudaraan sangat dekat dengan peritel. Hubungan persaudaraan ini melahirkan motif saling membantu, tepo seliro, saling berbagi dan berinteraksi dengan penuh kekeluargaan. Pelanggan utama yang berjarak 10 rumah kesamping kanan-kiri dan ke depanbelakang dari peritel, mempunyai hubungan darah yaitu keponakan, paman, bibi, saudara jauh dari ayah atau ibu peritel. Dalam tatanan pemerintahan desa atau kelurahan peritel dan pelanggan berada dalam satu rukun tetangga (RT), yang mana sering terlibat dalam kegiatan secara bersama-sama seperti pengajian, kendurenan, arisan, kerja bakti, dan berbagai bentuk gotong royong yang lain. Hal ini kemudian yang menyebabkan hubungan pelanggan dan peritel tersebut berasa melebihi hubungan saudara kandung.

Demikian pernyataan diatas disetujui oleh "Ibu Puah" dan "Ibu Lis" selaku peritel tradisional dari desa Blabak kecamatan Kandat dan dari kelurahan Blabak Kecamatan Kandat. Berikut pernyataan kedua informan pada saat wawancara:

\begin{tabular}{|l|l|}
\hline \multicolumn{1}{|c|}{ Informan } & \multicolumn{1}{c|}{ Pernyataan } \\
\hline Ibu Puah & $\begin{array}{l}\text { Sing blonjo teng mriki kabeh dulure dewe, wong liyo o yowis koyok } \\
\text { dulur dewe. Lha piye ben dino yo wong iki-iki ae ketemune.. yo dadi } \\
\text { konco ngaji, konco koyah, konco rewang, konco sambat hehehehe. } \\
\text { Dadi kulo anggep kabeh dulur kulo piyambak, mboten mikir golek } \\
\text { bathi sak okeh-okehe, enek sing nyuwun empon-empon, seledri, } \\
\text { godong jeruk, tempe bosok mek sithik yow is tak wenehi ae ora usah } \\
\text { bayar. }\end{array}$ \\
\hline Ibu Lis & $\begin{array}{l}\text { Sedoyo sederek mbak sing teng mriki, pernah misasan, mindoan, } \\
\text { tonggo omah, tonggo adoh lak sak deso nggih panggah kenal sae } \\
\text { dadose inggih sampun kados sederek piyambak. Umpami tumbas } \\
\text { yotrone kirang sekedik misale kirang sewu gedene sedoso ewu kulo } \\
\text { inggih mboten kabotan. Mergo pun kenal sae raose kados disilihi } \\
\text { dulur piyambak, toh mbenjing kan nggih mesti mbalik blonjo mriki } \\
\text { malih. }\end{array}$ \\
\hline
\end{tabular}

Dalam pengamatan dan dari pernyataan yang disampaikan kedua peritel dapat dimaknai bahwa peritel dan pelanggan adalah sama-sama perempuan sehingga unsur feminisme dari dimensi budaya Hofstade sangat kental terlihat. Ibu Puah dan Ibu Lis, mengakui bahwa yang menjadi 
pelanggannya adalah saudara mereka sendiri baik yang mempunyai hubungan darah maupun

bukan. Sehingga empati, keinginan menolong yang lemah, dan sikap-sikap irasional sering mereka lakukan, sebagai contoh belanjaan tetap diberikan meskipun uang yang dibayarkan pelanggan itu kurang, mencari untung sebanyak-banyaknya bukan motif utama mereka berdagang, dan meganggap semua pelanggan adalah saudara.

\section{b. Pelayanan Berlandaskan Kepercayaan}

Kedua peritel sama-sama mengakui bahwa saling percaya antara peritel dan pelanggannya merupakan modal utama dalam menjalankan usaha ini. Berdasarkan pengamatan dan diskusi ringan dengan kedua informan di lokasi toko kelontongnya masing-masing, tampak beberapa transaski didasarkan rasa saling percaya yang sangat tinggi peritel dan pelanggannya.

\begin{tabular}{|l|l|}
\hline \multicolumn{1}{|c|}{ Informan } & \multicolumn{1}{|c|}{ Pernyataan } \\
\hline Ibu Puah & $\begin{array}{l}\text { Toko kulo niki inggih ngeteniki enten e. Menawi enjing pas bukaan } \\
\text { dugi pasar, toko langsung bek tiyang tumbas, langsung mundut } \\
\text { barang-barang dagangan, mboten enten sing ngawasi. Dados } \\
\text { umpami wonten tiyang sing nakal sejo elek, ndelikne sayur nopo } \\
\text { sabun kulo inggih mboten ngertos. Tapi kulo yakin tiyang-tiyang } \\
\text { mboten wonten sing tego, wong kulo mboten tau nglarani, blonjo } \\
\text { mboten mbeto yotro mawon kulo layani. Prinsip kulo lek kulo nandur } \\
\text { sae,nggih InsyaAllah gusti bakal nglindungi. }\end{array}$ \\
\hline Ibu Lis & $\begin{array}{l}\text { Ibu-ibu ingkang blonjo teng ngriki roto-roto pun taunan dados } \\
\text { langganan kulo. Sayuran, bumbon, utawi kebutuhan dapur nggih } \\
\text { kulo berusaha nglengkapi kados selera e tiyang-tiyang. Kados mie, } \\
\text { sabun, kopi, teh, krupuk, minyak nggih nopo mawon sing kulo dep } \\
\text { niki, oleh kulo niteni suwunane tiyang-tiyang. Dados lek mlebet toko } \\
\text { inggih langsung mut-mut mundut piyambak-piyambak. }\end{array}$ \\
\hline
\end{tabular}

Bahwa kedua peritel Ibu Puah dan Ibu Lis sama-sama berkomitmen untuk menghargai, mempercayai dan ingin menyenangkan pelanggannya dengan cara mereka masing-masing. Ibu Puah mengakui sistem keamanan tokonya sangat lemah, namun dia berprinsip mempercayai pelanggannya tidak akan melakukan pencurian karena dia melayani dengan baik dan bahkan sering kali membantu pelanggan yang kekurangan uang belanja, didasarkan keyakinan kepada keimanannya.

Perilaku kedua peritel ini secara tidak langsung telah melaksanakan lima dimensi dalam kualitas jasa, yaitu reliability, assurance, tangibles, empaty dan responsiveness (Tjiptono, 2005). Kelima dimensi kualitas jasa ini semakin baik dilakukan karena didasari kepercayaan peritel kepada pelanggannya. Kepercayaan yang berarti amanah bagi peritel untuk selalu menyenangkan pelanggannya. Sehingga ketika pelanggan sudah senang maka loyalitas pelanggan akan semakin kuat, dan artinya peritel tidak akan pernah takut kehilangan pelanggannya. 


\section{c. Pola Pemasaran "Podho mlakune (usaha yang sama-sama berjalan)"}

Keberadaan peritel tradisional yang lebih dekat dengan konsumen akhir merupakan keuntungan tersendiri bagi tumbuhnya usaha mereka. Kedekatan secara geografis dan sosial ini membuat hubungan antra peritel dan pelanggan semakin bersifat humanisme (kemanusiaan) dari pada mencari keuntungan bisnis semata. Pernyataan ini didukung oleh pendapat yang disampaikan kedua peritel Ibu Puah dan Ibu Lis. Keduanya mengakui bahwa dalam menjalankan tokonya dan melayani pelanggannya prinsip winwin solution atau bahasa mereka "podho mlakune" itu yang dijadikan dasar dalam bertransaksi. Prinsip usaha yang diliputi nilai-nilai dan norma-norma seperti ini akhirnya melahirkan hubungan yang sifatnya jangka panjang dan ini menjadi keuntungan bagi kedua belah pihak. Ibu Puah menyampaikan nyaur nggowo (membayar belanja yang kemarin, dan membawa belanjaan hari ini), yang sering dilakukan dengan pelanggan membuat pelanggan tetap setia berbelanja di tokonya. Hal ini dikarenakan Ibu Puah tahu persis pelanggannya mempunyai penghasilan mingguan atau harian. Ibu Lis dengan toko yang lebih besar dan lengkap, prinsip "podho mlakune"(kerjasama saling menguntungkan) ini ditunjukkan dengan memberikan perlakukan khusus kepada pelanggan yang setia, yaitu memberikan hadiah saat menjelang hari raya, memberi kelonggaran pembayaran (nyaur nggowo), dan melakukan diskriminasi harga kepada pelanggan rumah tangga dan pelanggan yang memiliki warung. Dengan gaya transaksi masing-masing keduanya berhasil menjaga hubungan harmonis berjangka panjang dengan pelanggan masing-masing.

Perilaku bertransaksi kedua peritel ini dapat dianalisa mendalam dengan dimensi budaya (Hofstede, 1997). Dimensi-dimensi tersebut antara lain Power Distance, Indiviualism/collectivism, Masculinity / Femininity, dan Uncertainty Avoidance. Berikut pembahasan masing-masing dimensi berdasarkan pernyataaan dan observasi kepada peritel:

\section{Power Distance}

Ibu Puah yang tinggal di desa Blabak kecamatan Kandat kabupaten Kediri dan Ibu Lis yang bertempat tinggal di kelurahan Blabak kecamatan Pesantren Kota Kediri, menunjukkan perilaku bahwa peritel menempatkan dirinya pada perbedaan kekuasaan yang rendah, karena saat bertransaksi peritel menempatkan dirinya adalah mitra pelanggan dalam memenuhi kebutuhan masing-masing, tidak menekan pelanggan untuk mendapatkan keuntungan sebanyak-banyaknya dalam berdagang. 
Dengan bahasa lain dapat diartikan peritel tidak mengakui adanya perbedaan dan menganggap adanya persamaan tingkatan didalam masyarakat.

\section{Individualism/ Collectivism}

Kedua peritel menunjukkan sikap dan perilaku lebih mengedepankan kepentingan bersama dengan prinsip saling menguntungkan "podho mlakune" dalam menjalankan usahanya. Pada kebudayaan kolektivis, orang menerima tanggungjawab dari keluarga, kelompok masyarakat, dan suku sebagai bentuk kesetiaan. Kenyataan bahwa yang menjadi pelanggan mereka adalah saudara sedarah maupun saudara jauh dengan berbagai bentuk hubungan dalam kemasyarakatan, menjadikan peritel bersikap memiliki tanggung jawab untuk menjalin hubungan kebersamaan.

\section{Masculinity/ Femininity}

Nilai dominan ditunjukkan kedua peritel, dimana pada kebudayaan feminitas mencirikan adanya perhatian pada orang lain dan kualitas kehidupan, hubungan persaudaraan, dan peduli pada yang lemah. Hal ini ditunjukkan sangat jelas pada saat observasi dan wawancara dengan peritel. Pelanggan yang 95\% adalah perempuan melahirkan sikap empati yang dilandasi saling percaya, memperlunak cara pembayaran, saling membantu dalam memperbaiki kehidupan masing-masing dan loyalitas pelanggan yang sangat kuat. Bagi kedua peritel menciptakan hubungan kekeluargaan jauh lebih utama dibandingan sekedar mencari keuntungan, hal ini menjadi salah satu ciri kebudayaan feminitas, yaitu mempunyai orientasi masyarakat, dan status tidak begitu penting.

\section{Uncertainty Avoidance}

Selama masa pra penelitian sampai dengan masa observasi dan wawancara, Ibu Puah dan Ibu Lis menunjukkan sikap optimism yang sangat tinggi dengan didasari nilai-nilai keagamaan dan keyakinannya. Keyakinan bahwa jika berbuat baik akan dilindungi Allah SWT., jika tidak pernah menyakiti pelanggan maka pelanggan akan membalas dengan sikap yang sama, dan kenyataan bahwa pelanggan mereka adalah pelanggan setia yang sudah bertahun-tahun berbelanja di tokonya. Fakta-fakta ini menunjukkan bahwa kedua peritel memiliki tingkat penghindaran ketidakpastian yang rendah akan lebih santai sehingga praktik lebih tergantung prinsip dan penyimpangan akan lebih bisa ditoleransi, ada sikap saling percaya antar peritel dengan pelanggannya. Ketidakpastian mengenai masa depan adalah sebagai dasar kehidupan masyarakat, namun demikian pada kedua peritel yang memiliki tingkat 
ketidakpastiannya rendah, maka tidak pernah melakukan tindakan untuk mengurangi dampak ketidakpastian dengan teknologi, peraturan dan ritual. Hal ini dibuktikan sejak toko tradisional ini berdiri, tidak pernah dilengkapi dengan sistem pengamanan yang baik, misalnya ruang toko yang tidak dipasangi kaca keliling, tidak ada pelayan yang sekaligus sebagai pengawas saat pelanggan berbelanja, tidak ada CCTV, tidak ada tata tertib yang ditempel di dalam toko dan peritel tidak pernah melakukan ritual-ritual untuk mengatasi segala masalah (pencurian/ penipuan) dalam usahanya.

\section{Hasil dan Pembahasan berdasarkan Perspektif Pelanggan}

\section{a. Peritel adalah saudara}

Secara demografi dan sosiografi pelanggan berada dalam hubungan yang sangat dekat, terlelak dalam radius kurang 500m dalam satu dusun dengan budaya, tata nilai dan norma-norma sosial dan agama yang sama. Hubungan yang sangat dekat antara peritel tradisional dengan pelanggan meciptakan kedekatan emosional bahkan sangat tampak pada saat bertransaksi jual beli diantara keduanya. Informan yang berperan sebagai pelanggan adalah ibu rumah tangga yang sudah menjadi pelanggan di toko langganannya masing-masing lebih dari lima tahun, yaitu Ibu Rukayah yang berdomisili di desa Blabak kecamatan Kandat kabupaten Kediri sebagai pelanggan toko Ibu Puah dan Ibu Siti Zulaikah yang beralamat di kelurahan Blabak kecamatan Pesantren kota Kediri sebagai pelanggan toko Ibu Lis. Dalam wawancara saat berbelanja diperoleh informasi pembenaran pernyataan observasi ini dari kedua informan. Ibu Rukayah menyatakan bahwa "ngapain belanja jauh-jauh ke pasar kalo saudara sendiri yang lebih dekat juga menyediakan dan Alhamdulillah bisa memberi rejeki dan membantu saudara sendiri daripada ngasih untung orang lain". Makna dari pernyataan Ibu Rukayah adalah pelanggan memilih belanja di tempat saudara karena faktor jarak, keinginan menjaga silaturahmi dan lebih rela memberikan keuntungan pada peritel yang masih mempunyai hubungan darah dibandingkan belanja di toko milik orang lain. Hal yang sama disampaikan oleh Ibu Siti "meskipun di sini dekat dengan alfamart dan indomart tapi saya tetap membeli di warung bu Lis, karena dia yo tonggo yo konco ngaji yo konco arisan, dan kalo ada hajatan saya selalu nyambati dia untuk keperluan sayuran dan bumbu-bumbunya". Artinya bahwa Ibu Siti memilih belanja di toko Ibu Lis karena hubungan sosial yaitu teman dalam pengajian, arisan, tetangga (tidak punya hubungan darah), dan karena seringnya dibantu oleh peritel setiap kali punya hajat. 
Dominasi sifat perempuan yang diperkuat dengan faktor demografi (jarak yang sangat dekat antara peritel dan pelanggan), adanya hubungan sosial kekeluargaan inilah yang menjadikan pelanggan merasa nyaman dan loyal memilih berbelanja di toko tradisional terdekat dengan rumah untuk memenuhi kebutuhan mereka sehari-hari.

\section{b. Pelayanan berlandaskan kepercayaan}

Keramahan peritel saat melayani pelanggan, kemudahan-kemudahan yang diberikan saat pelanggan punya masalah pembayaran, kebebasan memilih sendiri barang belanjaan, dan adanya sistem tawar menawar sangat disukai oleh ibu-ibu pelanggan. Tawa, canda, perkataan tulus dan ekspresi bahagia begitu tampak dari para pelanggan saat transaksi jual beli berlangsung. Mimik dan gesture tubuh peritel dan pelanggan ini dibenarkan oleh pernyataan Ibu Rukayah dan Ibu Siti, bahwa "kami sudah saling menghargai, saling membantu, saling menghormati dan kami sangat mempercayai satu sama lain. Sering kali kami berbelanja dengan uang yang kurang tetapi mereka tetap mengizinkan kami membawa pulang semua belanjaan kami”. Landasan kepercayaan yang dipraktikkan oleh peritel inilah yang membuat para pelanggan semakin setia kepada peritel tradisional, terbukti telah menjadi pelanggannya lebih dari lima tahun.

\section{c. Pola Pemasaran "podho mlakune (usaha yang sama-sama berjalan)"}

Kedua pelanggan sama-sama mengakui bahwa kebutuhan dan kerjasama dengan peritel selama ini berjalan dengan prinsip dasar saling menguntungkan, bahkan peritel sering kali menawarkan bantuan dan keringanan pembayaran. Berdasarkan pengamatan dan diskusi ringan dengan kedua informan di lokasi toko kelontongnya masing-masing, tampak beberapa transaski didasarkan sikap saling menolong.

\begin{tabular}{|l|l|}
\hline \multicolumn{1}{|c|}{ Informan } & \multicolumn{1}{c|}{ Pernyataan } \\
\hline Ibu Rukayah & $\begin{array}{l}\text { Saya sering kali pesan lewat telepon di malam hari untuk dibelikan } \\
\text { sayur-sayur yang saya butuhkan, tanpa menitipkan uang sama sekali. } \\
\text { Keesokan harinya saat berbelanja, semua sayur yang saya pesan } \\
\text { sudah dikemas dan tinggal dibayar, malah kadang kalo uang saya } \\
\text { kurang yo tetap disuruh bawa. }\end{array}$ \\
\hline Ibu Siti & $\begin{array}{l}\text { Meskipun saya sering menawar tapi bu Lis tetap melayani dan } \\
\text { memberikan harga sepesial karena dia tahu kalo saya akan menjual } \\
\text { kembali dalam bentuk makanan jadi. Sehingga belanja saya selalu } \\
\text { diberi harga lebih murah dibanding ibu-ibu rumah tangga yang hanya } \\
\text { untuk dikonsumsi sendiri. }\end{array}$ \\
\hline
\end{tabular}

Bahwa kedua peritel Ibu Puah dan Ibu Lis dinilai oleh pelanggannya sama-sama berkomitmen untuk saling membantu dalam memenuhi kebutuhan masing-masing. Pelanggan rumah tangga tetap dilayani dengan ramah, nyaman dan mendapat jaminan bahwa barang belanjaan pesanannya akan dibelanjakan. Hal ini menunjukkan bahwa aspek reliability, assurance, tangibles, empaty dan responsiveness dilakukan 
sepenuhnya oleh peritel tradisional dalam menciptakan hubungan simbiosis mutualisme "podho mlakune".

\section{SIMPULAN \& SARAN}

\section{Simpulan}

1. Budaya yang ditunjukkan dalam tata nilai kehidupan, nilai perilaku, dan pedoman dalam bermasyarat oleh peritel tradisional dalam memenuhi kebutuhan pelanggan, didasarkan pada nilai kekeluargaan, kepercayaan dan komitmen saling membantu untuk kemajuan bersama. Dimensi budaya Hofstade Power Distance peritel menempatkan dirinya pada posisi kekuasaan yang rendah, karena saat bertransaksi peritel menempatkan dirinya adalah mitra pelanggan dalam memenuhi kebutuhan masing-masing, tidak menekan pelanggan untuk mendapatkan keuntungan sebanyak-banyaknya dalam berdagang. Collectivism yaitu sikap menjunjung kebersamaan saling menguntungkan dalam bertransaki disepakati oleh peritel tradisional terbukti dengan kemudahan pembayaran "nyaur nggowo", memberikan diskriminasi harga "podho mlakune" kepada pelanggan setia dan pedagang ecer atau pedagang warung, Femininity ditunjukkan dengan sikap empaty kepada pelanggan yang lemah dengan tidak mencari untung yang banyak dari pelanggan, dan menempatkan pelanggan sebagai saudara. Uncertainty Avoidance, keyakinan akan masa depan sangatlah positif berdasarkan akidah agama, bahwa perbuatan baik akan dibalas dengan kebaikan, menjadi landasan dalam bertransaksi dengan pelanggan, sehingga peritel tidak menggunakan teknologi dan ritual untuk menanggulangi masalah pencurian atau penipuan.

2. Sikap pelanggan atas pola pemasaran yang dilakukan oleh peritel tradisional menjadi sangat positif untuk terjadinya loyalitas jangka panjang. Sikap dasar saling mempercayai yang dipraktikkan peritel membuat pelanggan semakin nyaman, semakin percaya dan terbukti pelanggan telah menjadi pelanggan loyal lebih dari lima tahun di toko kelontong langganan masing-masing. Dimensi kualitas jasa yang meliputi reliability, assurance, tangibles, empaty dan responsiveness dilakukan sepenuhnya oleh peritel tradisional saat bertransaksi, menjadi dasar pelanggan untuk loyal dan tidak berpindah toko dalam memenuhi kebutuhan mereka sehari-hari.

3. Interaksi dan norma - norma subyektif antara peritel tradisional dan pelanggannya sangat kental dengan nilai-nilai luhur budaya masyarakat jawa yaitu penuh dengan kekeluargaan, saling membantu, saling mempercayai, dan sangat percaya dengan masa depan yang positif karena faktor keyakinan dalam beragama peritel cukup kuat. Prinsip usaha podho mlakune, kemudahan pembayaran nyaur nggowo, dan saling memberikan kepercayaan tinggi antara 
peritel tradisional dan pelanggan, serta diperkuat dengan kesamaan demografi dan sosiografi semakin memperkuat hubungan kedekatan keduannya di masa-masa yang akan datang.

\section{Saran}

1. Peritel tradisional perlu mengembangkan sikap waspada pada manajemen keuangannya, termasuk mengikis sikap terlalu percaya kepada pelanggan saat berbelanja. Hasil observasi menunjukkan bahwa beberapa pelanggan mengambil dan meletakkan barang dagangan dengan tidak beraturan, sehingga ruang belanja menjadi berserakan dan tidak nyaman bagi pelanggan yang lain saat akan mengambil atau mencari barang yang dibutuhkan.

2. Dalam rangka menciptakan pelanggan yang loyal dalam hubungan simbiosis mutualisme, baik peritel maupun pelanggan wajib mengembangkan sikap keterbukaan atau kejujuran dalam bertransaksi. Prinsip saling membantu harus diterapkan pada porsinya, sehingga peritel tidak akan mengalami kesulitas modal belanja akibat pelanggan yang terus menunda pembayaran utang belanjanya. Sedangkan bagi pelanggan tetap akan mendapatkan barangbarang kebutuhan sehari-hari dengan segala kemudahan dan kenyamanan yang diberikan oleh peritel tradisional.

3. Nilai-nilai budaya luhur dalam masyarakat perlu dilestarikan sesuai porsinya, sehingga tetap akan memberikan nilai kemanfaatan yang tinggi dalam kehidupan bermasyarakat khususnya dalam kegiatan perekonomian skala mikro di masyarakat.

\section{DAFTAR PUSTAKA}

Hakimah, E., \& Aliami, S. (2017). Makna menciptakan impulse buying bagi ritel kecil/ UMKM. In Prosiding Seminar Nasional dan Konfernsi Forum Manajemen Indonesia ke9. Semarang.

Hawkins, D.I Mothers bough, DL and Best R.J. 2007. Consumer Behavior: Marketing Strategi, 10 Ed, Mc Graw Hill, USA

Hofstede, Gert, 1997, Culture and Organizations, software of the Mind, Mc Graw Hill Companies, Inc.

Kamayanti A. 2015. Metodologi Penelitian Akuntansi. Jakarta: Yayasan Rumah Peneleh.

Levy, M., \& Weitz, B. A. (2009). Retailing Management (Fifth Edi). Mc Graw Hill. New York Mowen C. John and Michael Minor, 2002, Perilaku Konsumen, Alih bahasa: Lina Salim. Jilid 1, Edisi Indonesia, Erlangga, Jakarta

Pablo, S. (2018). Pengusaha: Industri Ritel Semester I-2018 Tumbuh 7-7,5\%. Retrieved from https://www.cnbcindonesia.com/news/20180622163406-4-20125/pengusaha-industriritel-semester-i-2018-tumbuh-7-75

Tjiptono, Fandi, 2005, Pemasaran Jasa, Banyu Media Publishing, Malang

Schiffman, Leon G, and Leslie Lazar Kanuk, 2000, Consumer Behavior, $7^{\text {th }}$ Edition, Prentice Hall, Inc.

Suprapti, Ni Wayan, 2010, Perilaku Konsumen, Udayana University Press, Denpasar https://marketing.co.id/12-karakter-unik-konsumen-indonesia 